\title{
Comprehensive Broiler Supply Chain Model with Vertical and Horizontal Linkages: Impact of US-China Trade War and USMCA
}

\author{
Hakan Unveren and Jeff Luckstead ${ }^{\star}$ (D) \\ Department of Agricultural Economics and Agribusiness, University of Arkansas, Fayetteville, AR 72701, USA \\ ${ }^{*}$ Corresponding author. Email: jluckste@uark.edu
}

\begin{abstract}
This paper builds a comprehensive supply chain model of the US broiler industry that accounts for corn and soybean meal, feed mills, breeders, hatcheries, grow-out farms, broiler processing, value-added processing, and international trade. The model is calibrated and simulated to analyze the effects of (1) corn and soybeans tariffs imposed by China and (2) change in the Canadian tariff-rate quota proposed under US-Mexico-Canada-Agreement. The first scenario indicates that feed price falls while supply increases, which decreases the production costs of breeders and grow-out farms. The second scenario shows that exports to Canada rise at the expense of exports to Mexico.
\end{abstract}

Keywords: Broiler industry; supply chain; tariffs; USMCA; vertical integration

JEL Classifications: Q11; Q13; Q18

\section{Introduction}

The US broiler industry is highly integrated with individual companies controlling multiple segments of the supply chain. Shocks to the broiler industry through changes in domestic or international policy can ripple through both the integrated and independent segments of the supply chain. The trade war that started in April 2018 led to China imposing tariffs on US corn and soybeans (Marchant and Wang, 2018), which impacts the broiler supply chain through changes in feed costs. Also, the United States, Canada, and Mexico negotiated the US-Mexico-Canada Agreement (USMCA) that, if ratified by the three countries, will expand the quota for US broiler exports to Canada. This paper analyzes the impact of corn and soybean price shocks due to Chinese tariffs on these two broiler feed ingredients and the USMCA policy changes in the broiler industry on the US broiler supply chain.

The broiler industry ${ }^{1}$ is an essential segment of US agriculture both in terms of production and consumption. US broiler production has grown since the 1960s due to rapid gains in productivity and reductions in production costs, which both stem from advances in science and industry structure through vertical integration (Reimund, Martin, and Moore, 1981). Specifically, new broiler breeds through improvements in genetics, better nutrition, enhanced disease control, and more efficient management of confined poultry have resulted in broiler production to become faster, cheaper, and safer (Perry, Banker, and Green, 1999). Vertical integration along the broiler supply chain has become commonplace, where individual companies produce and supply inputs to downstream production processes. Individual companies, called integrators, control genetic stocks

\footnotetext{
${ }^{1}$ The poultry industry designates chickens that are bred and raised specifically for meat as "broilers." 


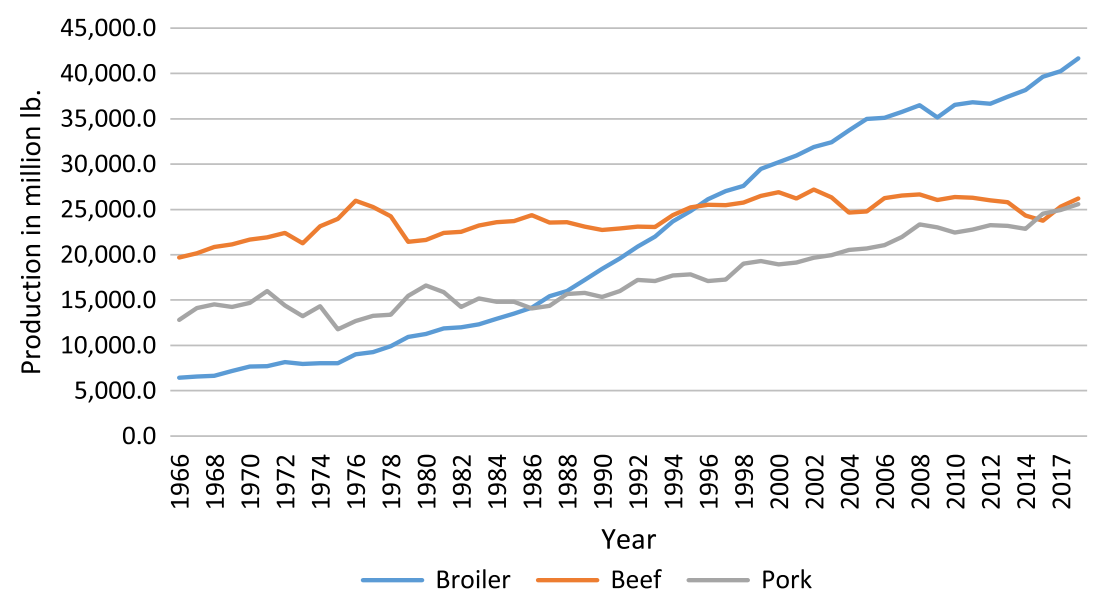

Figure 1. Trends in the US meat production from 1966 to 2017.

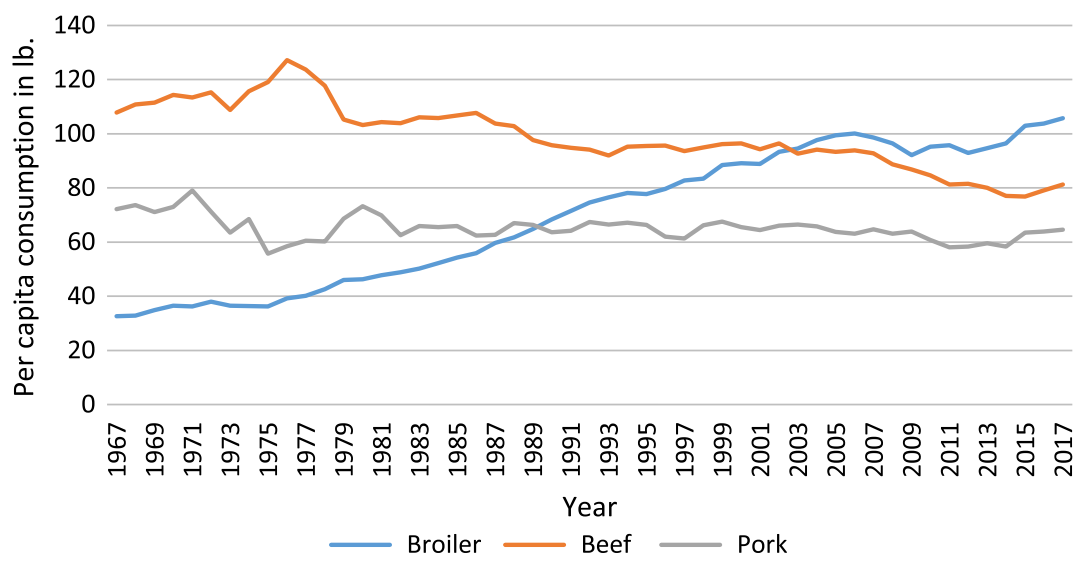

Figure 2. Trends in US per capita meat consumption from 1966 to 2017.

(breeder farms), feed, hatcheries, slaughter and processing plants, and transportation (Goodwin, 2005). Through both vertical integration and mergers, the number of firms operating in the broiler industry fell from 250 in 1950 to about 20 integrators in 2012. These 20 companies account for approximately $96 \%$ of broiler production, and the top three account for $50 \%$ of total broiler supply (Goodwin, 2005; MacDonald, 2014). Advancements in genetics, vertical integration, and concentration in the broiler industry led to more efficient production and lower average cost, which resulted in broiler production increasing from 6,437.1 million lb. in 1966 to 41,662 million lb. in 2017 (see Figure 1). Furthermore, broiler production surpassed that of pork in 1985 and beef in 1994 because of the substantially longer life cycle of beef cattle and swine. As a result, advances in the genetics stock of beef and pork take longer than that of broilers, and vertical integration in the beef and pork industry is less prevalent than in the broiler industry (Ward, 1997).

Figure 2 shows that US per capita broiler consumption has expanded from $32 \mathrm{lb}$. in 1966 to $105.74 \mathrm{lb}$. in 2017. Broiler consumption surpassed that of pork (which has remained relatively stable at an average of $65.19 \mathrm{lb}$. per capita) in 1988 and beef (which declined from a peak of $127.19 \mathrm{lb}$. per capita in 1976 to $81.26 \mathrm{lb}$. per capita in 2017) in 2002, becoming the number one source of meat. The popularity of chicken by US consumers occurred because of low prices 
due to rapid productivity growth and the expansion of supply; chicken meat is considered healthier than beef and pork; and processors provide an array of products such as whole chickens, chicken parts, and a plethora of value-added products (Davis et al., 2013). Within broiler meat, US consumers prefer white meat (chicken breast and wings) to dark meat (thighs and legs) by a 2-to-1 margin primarily for health reasons, as white meat includes more protein and less fat than dark meat (Arumugam, 2011). Consumers benefit from the rapid advances in productivity because broiler production has outpaced beef and pork production and broiler demand, resulting in relatively low broiler prices.

Exports dominate US broiler trade. With a 10-year average of 6.7 billion lb., US broiler exports are 55.8 times larger than US broiler imports. Since 2000, Russia and Mexico have been the top destinations, accounting for $17.9 \%$ and $13.5 \%$, respectively, of all US broiler exports. However, in recent years, US exports to Mexico dominated at around 20\% while exports to Russia evaporated. As exports to Russia dried up, apart from Mexico, no single market emerged as dominate, and exports to Canada, Hong Kong, Cuba, Angola, China (Taiwan), and Guatemala all range between $3.5 \%$ and $6 \%$. Leg quarters ${ }^{2}$ dominate exported broiler meat products, accounting for $59.4 \%$ of all exports in terms of value and $66.6 \%$ in terms of quantity. On the import side, before 2008, over $95 \%$ of US imports came from Canada. However, after 2008, Chile rapidly gained US market share, going from $1.75 \%$ of US imports in 2008 to $58 \%$ by 2018 . At the same time, Canada's market share shrank from $98.2 \%$ in 2008 to $40.9 \%$ in 2018 .

With feed costs ranging between $65 \%$ and $75 \%$ of the total cost for US broiler producers (Weaver, 2014), the availability of cheap feed is crucial to overall profitability and production. Corn and soybean meal account for $44 \%$ and $26 \%$, respectively, of broiler feed, making them the primary feed inputs. These two key ingredients make up around $70 \%$ of broiler feed prices (IFEEDER, 2017); any shock to the corn and soybean industry impacts the broiler supply chain through feed cost. Under the Trump administration, the United States and China are engaged in a trade war, which has directly affected the bulk of agricultural products in the United States. In response to US tariffs on many Chinese imports, China imposed retaliatory tariffs on US soybean and corn imports, among other goods. ${ }^{3}$ Since this conflict, the value of US corn exports to China decreased by $64.8 \%$ from $\$ 142$ million in 2017 to $\$ 50$ million in 2018, and US soybean exports to China declined by $74.5 \%$ from $\$ 12.22$ billion in 2017 to $\$ 3.12$ billion in 2018 (USDA, 2018d), which led to an increase in quantities in the US domestic market. According to Swanson, Coppess, and Schnitkey (2018), US domestic soybean meal prices dropped approximately $24.2 \%$ from $\$ 10.34$ to $\$ 7.84$, and corn prices declined $18.3 \%$ from $\$ 3.78$ to $\$ 3.09$ between March and July 2018..$^{4}$ Given the importance of feed in broiler production, this study analyzes the impact of the decline in corn and soybean meal prices on the broiler supply chain.

In late 2018, the United States, Mexico, and Canada signed the USMCA, which, as of December 2019, has not been ratified by the three countries (USTR, 2018). USMCA policy changes for US agriculture include enhanced access to Canadian dairy and poultry markets. For the broiler industry, market access is expanded through changes to the Canadian tariff-rate quota (TRQ). Once ratified, USMCA will increase the quota for US products to enter Canada tariff-free from 47,000 to 57,000 MT; once the quota is met, a tariff of $249 \%$ is applied to US exports to Canada. This study analyzes the impacts of the change in the Canadian TRQ throughout the entire broiler supply chain.

Several large-scale models consider poultry but do not allow for broiler-specific analyses because poultry is aggregated with other meat sectors (e.g., the GTAP CGE model [Corong

\footnotetext{
${ }^{2}$ We include HS code 207130000 and 207140010 in our calculation of leg quarters.

${ }^{3}$ The United States is consistently the largest producer of soybeans, and China is the largest buyer of US soybeans (Cang and Sedgman, 2018). China was the third largest buyer of US corn in 2013, but since then, the quantity of US corn exported to China has decreased due to Chinese policies (Corn Trade, 2017; USDA, 2018d). With China also imposing tariffs on US corn, the trade war will negatively impact US corn producers (Daniels, 2018).

${ }^{4}$ Swanson, Coppess, and Schnitkey (2018) find that the price of corn price decreased by $\$ 0.41$ between May and June.
} 
et al., 2017]). The Food and Agricultural Policy Research Institute (FAPRI) maintains an econometric multi-commodity model, which includes poultry (FAPRI, 2004, 2018). As part of the poultry supply sector, the FAPRI model specifies the number of pullets placed, broiler production, feed costs, and retail sectors. However, the complete supply chain and structure of integrators are not fully captured, as hatcheries and breeders are modeled as one stage of production, and valueadded broiler products (which account for approximately $49 \%$ of the market share [NCC, 2018]) are not explicitly modeled. The partial equilibrium Aglink-Cosimo model (OECD, 2014) disaggregates poultry production and disappearance but mainly focuses on world agriculture markets. Therefore, many of the vertical supply relations are not modeled, and poultry is not the primary focus of these models. Given data availability, this study builds a poultry supply chain to model. In doing so, the model disaggregates hatcheries and breeders as two separate segments and includes valued-added broiler products.

A large portion of the literature analyzing the broiler industry focuses on the impact of a specific event on one particular segment of the industry. For example, Thomsen and McKenzie (2001) investigated the effects of food recalls and the ensuing financial support from the government on meat and poultry firms that are publicly traded. Dahlgran and Fairchild (2002) examined the severity of financial losses because of a decrease in demand for chicken meat due to adverse food safety news. Ollinger, MacDonald, and Madison (2005) considered the impact of technological change on the US poultry industry. Ollinger (2011) investigated the increase in plant size and economies of scale in the poultry, cattle, and pork industries as the government implemented the Hazard Analysis and Critical Control Points (HACCP) system. Holt and McKenzie (2003) analyzed the impact of supply shocks on US broiler producers' price expectations by incorporating the additional information provided by future prices into a standard price regression. Goodwin, McKenzie, and Djunaidi (2003) examined price relationships among chicken parts in the wholesale broiler market using a vector autoregressive regression time series modeling approach. Awokuse and Bernard (2007) studied the structure of the US broiler market by considering if the law of one price holds across urban areas in the Northeast, South, Midwest, and West. Suh and Moss (2016) analyzed substitution between distiller's dried grain with solubles and corn-based feed as production and prices change using a dynamic linear logic model. Our analysis differs from these agent-specific studies by considering the impact of changes in trade policies on the whole broiler supply chain.

International trade is an important component of poultry markets. Implementing time series analysis, Awokuse and Yuan (2006) and Davis et al. (2014) analyzed the impact of exchange rate volatility on US poultry and broiler exports and the international market as a whole. International trade agreements played an important role in poultry trade. For example, Moschini and Meilke (1991) studied tariffication under General Agreement on Tariffs and Trade (GATT) on the US-Canadian poultry market. Murphy et al. (1993) implemented an Armington trade model to forecast the impact of heightened trade protections and the implications of the Uruguay Round of the GATT. Peterson and Orden (2005) examined the removal of tariffs, TRQs, and sanitary regulations on international poultry markets using a competitive partial equilibrium spatial model with heterogeneous (high-value white meat and low-value dark meat) goods. Sanitary standards impact on food trade, particularly in poultry markets. Salin, Hahn, and Somwaru (2005) used a mathematical programming model to examine the impact of changes in sanitary requirements on broiler trade in the Americas. Wieck, Schlüter, and Britz (2012) implemented gravity model estimation to perform ex post analysis of avian influenza-related quarantine and utilized simulation methods to quantify the welfare effects of trade bans resulting from avian influenza. Zhou, Li, and Lei (2019) analyzed the impact of nontariff measures and avian influenza outbreaks on Chinese poultry exports. Our analysis differs from these papers by examining the impact of international policies on the US poultry supply chain, which includes both US poultry exports and domestic sales at the top end.

The specific objectives of this study are to: (1) develop a model of the US broiler supply chain that captures the vertical and horizontal linkages, (2) collect data for all segments of the US broiler supply 
chain, (3) calibrate the model to accurately represent the data, and (4) run two counterfactual analyses to study the impact of corn and soybean meal price shocks resulting from the US-China trade war and the USMCA broiler policy changes on the broiler industry. This study is the first to provide a comprehensive, quantitative analysis of the impacts of two important policy issues (US-China trade war and USMCA) on quantities, transfer prices, and market prices for each segment (corn and soybean meal, feed mills, breeders, hatcheries, grow-out farms, broiler processing, value-added production, domestic consumption, and trade) of the broiler supply chain.

\section{Model}

The supply chain model consists of corn and soybean meal, feed mills, breeders, hatcheries, growout farms, broiler processing, value-added production, and markets. The broiler industry is highly integrated (with the integrator controlling feed mills, breeders, hatcheries, broiler processing, and value-added), and a profit-maximizing agent controls each stage along the supply chain, except for corn and soybean meal which are modeled with reduced-form supply functions. The supply chain arises from upstream agents supplying or selling inputs to downstream agents. In addition to vertical linkages, two horizontal linkages exist: (1) breeders and grow-out farms both use feed as an input and (2) whole chickens, chicken parts, and chickens for further processing all demand live chickens from grow-out farms. All output and input prices along the supply chain are determined endogenously through market-clearing conditions. Here, we discuss the main assumptions of the model; see online supplementary Appendix A for the full mathematical model.

Figure 3 depicts the eight segments along the broiler-industry supply chain, where the dashed boxes indicate independent farmers/producers, circles indicate stages of production owned by an integrator, the hexagon represents markets for final broiler products, and descriptions next to an arrow are the output of the previous stage. First, the most upstream segment is independent raw material producers who sell corn and soybean meal to feed mills. Second, the integrator-owned feed mills supply feed to breeder farms and grow-out farms. Third, independent breeder farms produce fertilized eggs for hatcheries. ${ }^{5}$ Fourth, with the fertilized eggs, integrator-owned hatcheries produce day-old chicken (DOC). Fifth, independent grow-out farms sign contracts with integrators for DOC and feed to raise broiler chickens. ${ }^{6}$ Sixth, integrator-owned processing plants utilize broiler chickens and slaughter them to produce whole chickens, chicken parts for consumption, and prepare live chickens for the value-added segment. Seventh, integrator-owned value-added plants also utilize slaughtered chicken from processing plants and other inputs (e.g., oil, flour, eggs, spices) to produce processed (value-added) chicken products. ${ }^{7}$ Eighth, market prices are determined for whole chickens, chicken parts, and processed (value-added) chicken via the market-clearing conditions, where total production equals total domestic consumption and exports. Also, prices are endogenously determined through equilibrium conditions for each segment in the supply chain: corn and soybean prices are determined by the equilibrium conditions where total demand for corn and soybean meal by feed mills equals the supply of corn and soybean meal to the broiler industry. Within the integrator, transfer prices between segments are determined by setting supply equal to the demand for feed, fertilized eggs, and DOCs.

\footnotetext{
${ }^{5}$ Note that upstream from the breeder farms are both integrator-controlled and private genetic companies that provide parent flocks. However, because public data on this segment are not available, we are not able to include the primary breeding sector in the supply chain model.

${ }^{6}$ The contracts between the integrators and grow-out farms are very detailed and typically specify conditions beyond DOC and feed. For example, the integrators provide veterinary and management services (Vukina and Leegomonchai, 2006). However, for the model, we focus on only DOC and feed because they are critical to the broiler supply chain.

${ }^{7}$ It is common for value-added processing plants to utilize chicken parts from processing plants for value-added production. However, data do not exist for splitting chicken parts between market sales and value-added processing, and the diagram depicts the assumptions based on data availability.
} 


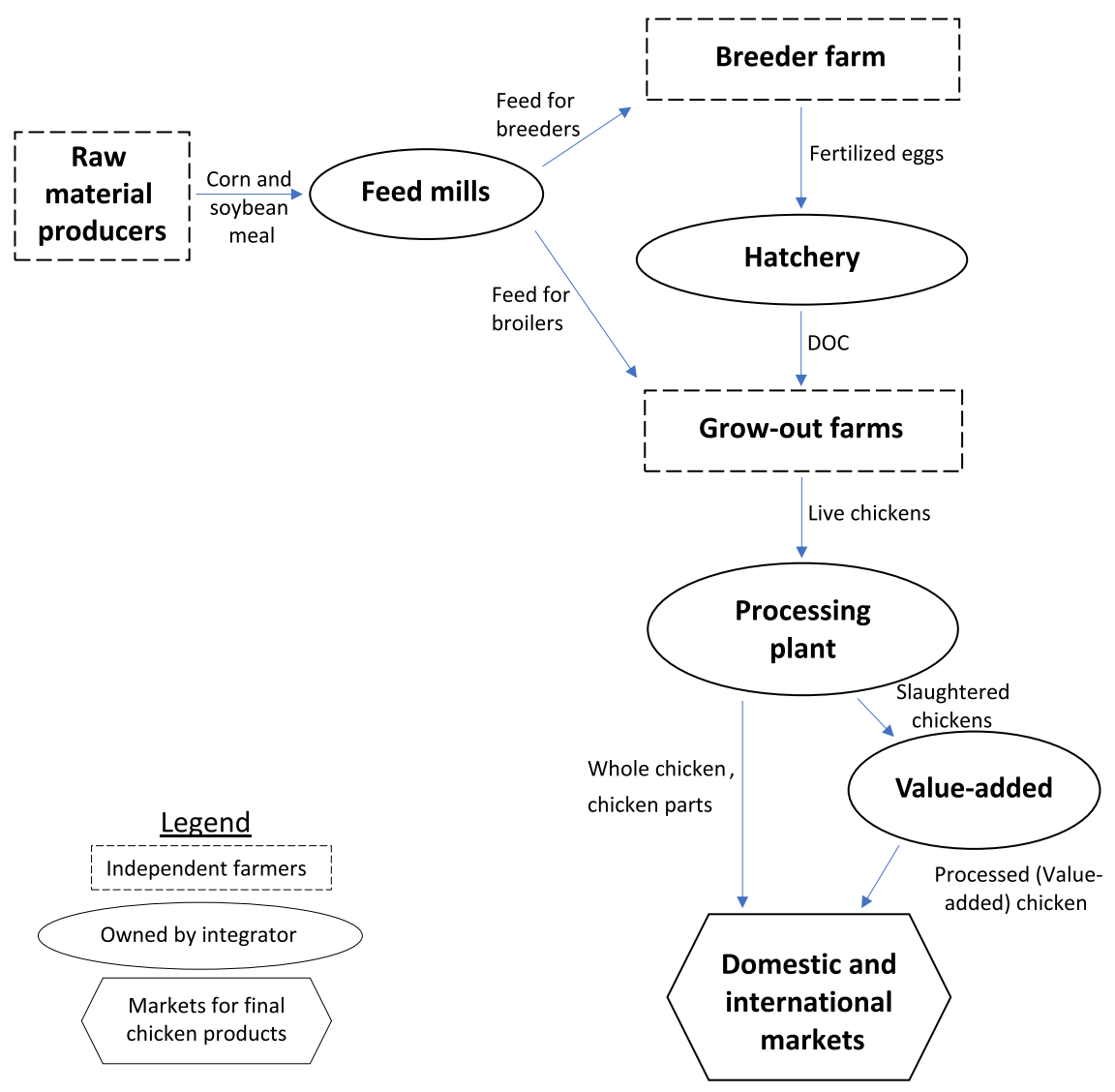

Figure 3. Broiler industry supply chain.

\section{Data and calibration}

This paper utilized annual data from 2012 to 2017 from secondary government reports and databases. For each variable discussed below, our baseline data are the average over these 3 years, unless otherwise noted. Data are collected for quantities and prices of all outputs and inputs in the model and quantities exported.

For corn and soybeans, the total supply and imports to the feed industry are obtained from the Feed Grains Database (USDA, 2018c). One lb. of soybean yields $0.792 \mathrm{lb}$. of soybean meal (USSEC, 2018). The percentage of corn and soybean meal utilized in the broiler industry came from the Animal Food Consumption report (IFEEDER, 2017), but these percentages are published for 2016 only. Corn and soybean meal prices are taken from Quick Stats (USDA, 2018h). Based on the National Agricultural Statistics Service (USDA, 2018b), the corn and soybean meal prices are converted into the broiler feed price:

$$
\rho^{F}=\left(0.58 \times \frac{p^{C}}{56}\right)+\left(0.42 \times \frac{p^{S M}}{60}\right)
$$

Based on Animal Food Consumption Report (IFEEDER, 2017), in 2016, breeders and grow-out farms accounted for about $4 \%$ and $96 \%$ of feed use, respectively.

For the breeder farm, the number of fertilized hatching eggs is obtained from Livestock and Meat Domestic Data (USDA, 2018e). For the hatcheries, the number of DOC is collected from 
Quick Stats (USDA, 2018h), which accounts for fertilized eggs that did not hatch. The prices of fertilized eggs and DOCs are obtained from Clauer (2012).

For grow-out farms, the quantity of broiler chickens in lb. and price is obtained from Quick Stats (USDA, 2018h), which accounts for mortality rates. Broilers are sold to processing plants where they are slaughtered for three different markets: whole chickens, chicken parts (which consists of three subsegments: chicken breast, wings, and dark meat), and value-added processing. The quantity of broilers is transformed into the dress weight, which is $71 \%$ of the live weight (Schweihofer, 2011). Then, the total dress weight quantity is divided into whole chickens, chicken parts, and broilers processed for the valued-added processing based on percentages $(11 \%, 40 \%$, and $49 \%$, respectively) reported by the National Chicken Council (NCC, 2018). ${ }^{8}$ For chicken parts, $41 \%$ of the dress weight is chicken breast, $48 \%$ is dark meat, and $11 \%$ is wings (Chicken Parts, 2018). The prices of a whole chicken, chicken breast, and dark meat are obtained from U.S. Bureau of Labor Statistics (2018). Due to a lack of data for the national chicken wing price, we utilized the wing price of the southern states which are collected from the Agricultural Marketing Service (USDA, 2018g, p. 235). Because data for the price of chickens processed for the value-added segment are not available, we assume this price is equal to that of chicken parts.

According to the Economic Research Service (USDA, 2018a), exports of whole chickens and chicken breasts are negligible and are excluded from the analysis. Therefore, domestic consumption equals the production of whole chickens and chicken breasts. Data on Mexican, Canadian, and Rest of the World (ROW) imports of wings and dark meat are collected from the Foreign Agricultural Service (USDA, 2018f). US domestic consumption of chicken wings and dark meat is calculated by subtracting exports from total production.

With no data on total value-added production of the broiler supply chain, we assume that the quantity of broilers processed for value-added and value-added total output are equal to each other. Trade data for value-added products are taken from UNComtrade (2018). US domestic consumption of value-added products is the difference between total production and exports. We assume the price of value-added products is $30 \%$ higher than the price index for chicken parts. We perform sensitivity analyses on this assumption.

With respect to tariff and transportation cost variables, Canada applies a TRQ on imports of poultry products (World Trade Organization, 2019). The TRQ is zero on imports under 47,000 MT and $249 \%$ on imports above this quota for the United States. Therefore, we applied a weighted average tariff rate for US-Canada broiler trade of $161 \%$. For Mexico, under NAFTA, imports of US dark meat are duty-free (Hernandez and Hernandez, 2015). The tariff on US exports of broiler products to ROW is subject to a trade quantity-weighted average tariff rate of $25 \%$ (World Trade Organization, 2018). The North American transportation costs are $\$ 0.095$ and $\$ 0.077$ per lb. for exports to Mexico and Canada, respectively. These transportation costs are calculated using the following data. A semitruck can carry roughly 55,000 lb. of broiler meat (Truckers Report, 2018). The net transportation costs from Springdale, Arkansas (a major chicken producing region in the United States) to Mexico City, Mexico and Montreal, Canada are \$5,221.00 and \$4,255.00 per truck, respectively (Transportation Cost, 2019). Also, Canada applies a $\$ 200$ fee for customs paperwork per truck, and $10 \%$ of trucks are reinspected at the US-Canadian border at the cost of $\$ 400$ (Transportation Cost, 2019). Therefore, an additional $\$ 240$ is added to Canada's transportation cost rate. The transcontinental transportation cost is $\$ 0.114$ per lb. for ROW. This transportation cost is calculated using the following data. A cargo container on an ocean cargo ship can carry $50,000 \mathrm{lb}$. of broiler meat. The net transportation cost is $\$ 7,015, \$ 7,110, \$ 5,450$, and $\$ 5,200$ for Hong Kong, South Korea, the Netherlands, and Brazil, respectively (Transportation Cost,

\footnotetext{
${ }^{8}$ The National Chicken Council data show changes in trends over time. Between 1962 and 2015 (values after 2010 are estimated), the share of whole chickens decreased dramatically from $83 \%$ to $11 \%$, while the percentage of chicken parts increased from $15 \%$ to $40 \%$, and the share of processed (value-added) chicken increased dramatically from $2 \%$ to $49 \%$.
} 
2019). Based on the cost of these four ports, the trade value-weighted average (averaged over 2012 and 2017) is calculated (USDA, 2018d).

With the data defined above, we calibrate the parameters in the production functions and reduced supply and demand functions. Because of relatively strict formula requirements for producing feed from corn and soymeal, and grow-out farms are unable to substitute feed for DOCs, we assume a lower elasticity of substitution of 0.2 between inputs. Given the duality between production function and cost functions, we follow Rutherford (2002) to calibrate the share parameters, and the returns to scale parameters are calculated as the total cost of production divided by the total value of production. The details of the remaining parameters are provided in online supplementary Appendix B.

\section{Simulation results}

The supply chain model for the US broiler industry is simulated to analyze the impact of policy shocks on the broiler supply chain. Specifically, based on profit maximization, supply and input demand functions are derived in terms of endogenous prices (see online supplementary Appendix A for details). The derived functions are substituted into the market-clearing conditions, and the equilibrium conditions are solved numerically for the endogenous market prices (corn $p^{C}$, soybean meal $p^{S M}$, breeder $p^{B}$, grow-out $p^{G}$, whole chicken $p^{W}$, breast meat $p^{B r}$, wings $p^{W i}$, dark meat $p^{D}$, and value-added $p^{V A}$ ) and transfer prices (feed $\rho^{F}$, DOCs $\rho^{H}$, and processed chicken for value-added $\rho^{P V}$ ). With equilibrium prices solved, quantities are calculated using the supply and input demand functions.

The US-China trade war and USMCA trade agreement both impact the broiler industry. In early 2018, China imposed retaliatory tariffs on corn and soybeans, among other agricultural and nonagricultural products. These tariffs indirectly impact the broiler supply chain by influencing the supply and market price of corn and soybean meal. As previously discussed, corn and soybean meal are major inputs in this industry because they account for about $44 \%$ and $26 \%$ of feed inputs, respectively, and feed constitutes about $70 \%$ of the total cost of broiler production. With the Chinese tariffs on corn and soybeans lowering the Chinese demand for US corn and soybeans, the supply of these products in the US domestic market expands, which lowers the price of these commodities. As a result, this study analyzes the impact of a decline in domestic corn and soybean meal prices by $18 \%$ and $24 \%$, respectively (Swanson, Coppess, and Schnitkey, 2018), resulting from the Chinese tariffs. If USMCA is ratified by the United States, Mexico, and Canada, market access for US producers to the Canadian broiler market will expand, as the quota for US products to enter Canada tariff-free is set to rise to 57,000 MT from the current level of $47,000 \mathrm{MT}$. As a result, the weighted average tariff will fall from $161 \%$ to $142 \%$. This study quantifies the impact of a decline in this quota. Consequently, three scenarios are considered: (1) the baseline maintains current values for all policy variables and replicates the benchmark data; (2) the first alternate scenario considers the impact of a price shock on corn and soybean meal; (3) the second alternate scenario analyzes the impact of expanding the quota Canada imposes on US exports.

The results of the two alternate scenarios are compared to the baseline scenario to quantify the impacts of an input price shock and expanded market access in Canada. Table 1 reports the baseline values for quantities and impacts of the two alternate scenarios in percentage change relative to the baseline. Table 2 presents the baseline values for prices and impacts of the two alternate scenarios in percentage change relative to the baseline. Table 3 reports the baseline values for domestic consumption and exports and the impacts of the two alternate scenarios in percentage change relative to the baseline. 
Table 1. Impacts on supply chain quantities

\begin{tabular}{|c|c|c|c|}
\hline Variables & Baseline values & $\begin{array}{l}\text { Corn and soybean price } \\
\text { shock ( } \% \text { change) }\end{array}$ & $\begin{array}{c}\text { Expand Canadian quota on } \\
\text { US products ( } \% \text { change) }\end{array}$ \\
\hline Corn $Q^{C}$ & 0.04 (mil. tonne) & 25.59 & 0.03 \\
\hline Soybean meal $Q^{S M}$ & 0.02 (mil. tonne) & 27.65 & 0.05 \\
\hline Broiler feed $Q^{F}$ & 0.09 (mil. tonne) & 12.21 & 0.02 \\
\hline Fertilized eggs $Q^{B}$ & 1.09 (bil.) & 6.69 & 0.01 \\
\hline DOCs $Q^{H}$ & 0.77 (bil. head) & 7.34 & 0.01 \\
\hline Broiler chicken $Q^{G}$ & 52.48 (bil. lb.) & 9.96 & 0.02 \\
\hline Whole chicken $Q^{W}$ & 4.09 (bil. lb.) & 6.70 & -0.11 \\
\hline Chicken breast $Q^{B r}$ & 1.12 (bil. lb.) & 2.95 & 0.09 \\
\hline Dark meat $Q^{D}$ & 9.43 (bil. lb.) & 2.95 & 0.09 \\
\hline Chicken wings $Q^{W i}$ & 2.37 (bil. lb.) & 2.95 & 0.09 \\
\hline Proc. for value-added $Q^{P V}$ & 18.26 (bil. lb.) & 3.27 & -0.05 \\
\hline Value-added Proc. $Q^{V A}$ & 18.26 (bil. lb.) & 2.48 & -0.04 \\
\hline
\end{tabular}

Table 2. Impacts on prices

\begin{tabular}{|c|c|c|c|}
\hline Variables & Baseline value & $\begin{array}{l}\text { Corn and soybean price } \\
\text { shock (\% change) }\end{array}$ & $\begin{array}{l}\text { Expand Canadian quota on } \\
\text { US products ( } \% \text { change) }\end{array}$ \\
\hline Corn $p^{C}$ & 166.14 (\$/tonne) & -18.42 & 0.16 \\
\hline Soybean meal $p^{S M}$ & 420.43 (\$/tonne) & -24.76 & 0.07 \\
\hline Feed price $\rho^{F}$ & 266.21 (\$/tonne) & -11.51 & 0.14 \\
\hline Fertilized eggs $p^{B}$ & 3.36 (\$/dozen) & 7.09 & 0.17 \\
\hline DOCs $\rho^{H}$ & 4.32 (\$/dozen head) & 7.13 & 0.17 \\
\hline Broiler chicken $p^{G}$ & 0.55 (\$/lb.) & -8.37 & 0.14 \\
\hline Whole chicken $p^{W}$ & $1.47(\$ / \mathrm{lb})$. & -2.83 & 0.05 \\
\hline Chicken breast $p^{B r}$ & $3.33(\$ / \mathrm{lb})$. & -1.92 & -0.06 \\
\hline Chicken wings $p^{W i}$ & $1.72(\$ / \mathrm{lb})$. & -3.28 & -0.03 \\
\hline Dark meat $p^{D}$ & 1.55 (\$/lb.) & -4.88 & 1.13 \\
\hline Proc. for value-added $\rho^{P V}$ & 1.00 (\$/lb.) & -2.39 & 0.05 \\
\hline Value-added Proc. $p^{V A}$ & 2.99 (\$/lb.) & -1.63 & 0.04 \\
\hline
\end{tabular}

\subsection{Corn and soybean meal price shock}

This scenario measures the effect of an $18 \%$ and $24 \%$ decline in domestic corn and soybean meal prices resulting from the Chinese tariffs. The lower price of corn and soybeans reduces the cost of production for feed, which shifts the feed supply curve to the right. The simulation analysis predicts that the supply of feed expands by $12.21 \%$ and the price of feed to fall by $11.51 \%$. As seen in Figure 2, feed is an important input in two downstream segments-breeder farms and grow-out farms-which creates a horizontal linkage in the feed segment. Because hatcheries are downstream from breeder farms but upstream from grow-out farms in the supply chain, the change 
Table 3. Impacts on domestic consumption and exports

\begin{tabular}{|c|c|c|c|}
\hline Variables & Baseline value (lb.) & $\begin{array}{c}\text { Corn and soybean price } \\
\text { shock ( } \% \text { change) }\end{array}$ & $\begin{array}{l}\text { Expand Canadian quota on } \\
\text { US products ( } \% \text { change) }\end{array}$ \\
\hline \multicolumn{4}{|l|}{ Whole chickens } \\
\hline Domestic consumption & 4.09 & 6.70 & -0.11 \\
\hline \multicolumn{4}{|l|}{ Chicken breast } \\
\hline Domestic consumption & 6.09 & 2.95 & 0.09 \\
\hline \multicolumn{4}{|l|}{ Chicken wings } \\
\hline Domestic consumption & 1.58 & 3.15 & 0.03 \\
\hline Exports to Mexico & 0.01 & 1.11 & 0.01 \\
\hline Exports to Canada & 0.02 & 3.01 & 7.31 \\
\hline Exports to ROW & 0.16 & 1.10 & 0.01 \\
\hline \multicolumn{4}{|l|}{ Dark meat } \\
\hline Domestic consumption & 0.89 & 11.96 & -2.51 \\
\hline Exports to Mexico & 1.27 & 1.19 & -0.26 \\
\hline Exports to Canada & 0.28 & 11.35 & 15.76 \\
\hline Exports to ROW & 4.60 & 1.17 & -0.26 \\
\hline \multicolumn{4}{|l|}{ Value-added } \\
\hline Domestic consumption & 18.26 & 2.50 & -0.06 \\
\hline Exports to Mexico & 0.07 & 0.56 & -0.01 \\
\hline Exports to Canada & 0.03 & 2.43 & 11.98 \\
\hline Exports to ROW & 0.14 & 0.56 & -0.01 \\
\hline
\end{tabular}

in feed price impacts breeder farms directly as the cost of feed falls and indirectly as lower feed costs expand grow-out farms demand for DOCs, which raises hatcheries' demand for fertilized eggs produced by breeder farms.

Specifically, for breeder farmers, low feed cost reduces the production cost for breeder farms, which shifts the supply of fertilized eggs to the right, expanding production and putting downward pressure on the equilibrium price of fertilized eggs. Concurrently, the demand for fertilized eggs by hatcheries also expands as the production of DOCs increases to meet grow-out farms higher demand for DOCs as live bird (broiler chicken) production rises. This higher demand further expands the production of fertilized eggs but puts upward pressure on the equilibrium price of fertilized eggs. The simulation shows that the expansion in demand for fertilized eggs offsets the rise in the supply of fertilized eggs as the equilibrium quantity of fertilized eggs expands by $6.69 \%$ and the price of fertilized eggs rises by $7.09 \%$.

For hatcheries, the costs of inputs rise as the price of fertilized eggs expands, contracting supply and putting upward pressure on the price of DOCs. However, as previously discussed, the demand for DOCs expands as the production of grow-out farms expands, putting upward pressure on both equilibrium quantity and price. The results show that the demand effect outweighs the supply effects, and the equilibrium quantity of DOCs expands by $7.34 \%$ and price rises by $7.13 \%$.

Grow-out farms experience two counteracting input impacts: the decline in the price of feed and the increase in the price of DOCs. The fall in the feed price is a direct effect of the lower corn and soybean meal prices, which expands production, while the rise in the price of DOCs is an 
indirect effect of higher demand, which dampens production. This result highlights the importance of the vertically integrated supply chain: The increase in production of grow-out farms would be overestimated if the price of DOCs was assumed constant and the upstream hatchery and breeder segments were excluded from the model. The results show that the direct effect of lower feed cost dominates the indirect effect of the higher cost of DOCs, and the supply curve for grow-out farms shifts right. As a result, the production of broiler chickens expands by $9.96 \%$ and the price declines by $8.37 \%$.

The decline in the price of broiler chickens benefits the two downstream segments (processing plants and value-added plants) because the lower price reduces production costs. With input prices falling, the supply curves of these downstream segment shift to the right, causing production to expand for whole chickens by $6.70 \%$, chicken parts (breast meat, wings, and dark meat) by $2.95 \%$, and processed chicken for valued-added production by $3.27 \%$. As production expands, the prices of these commodities fall modestly. With lower prices, domestic consumption for the non-trade products of whole chickens and chicken breasts increases by $6.70 \%$ and $2.95 \%$, respectively. Consumption of whole chickens expands more than chicken breasts because the elasticity of demand for whole chickens is larger than that of chicken breasts. For the traded products, domestic consumption of wings and dark meat expands by $3.15 \%$ and $11.96 \%$, respectively. Again, the consumption of wings is less than the consumption of dark meat because the elasticity of demand for the former is lower than the latter. Exports of wings and dark meat to Canada expand by 3.01\% and $11.35 \%$, while exports to Mexico increase by $1.11 \%$ and $1.19 \%$, respectively. With Canadian preferences similar to that of the United States, the elasticities of demand for Canadian imports are higher than for Mexico, implying the quantity imported will be larger for Canada than Mexico for the same reduction in price. The results for the ROW are similar to those of Mexico.

With a lower price of processed chicken, the cost of value-added chicken processing also falls, leading to an increase in production. The lower costs cause equilibrium sales to rise by $2.48 \%$ and price to fall by $1.63 \%$. Domestic consumption expands by $2.50 \%$, and exports to Canada rise by $2.43 \%$, while exports to Mexico rise by only $0.56 \%$.

\subsection{USMCA policy}

Next, we quantify the impact of the quota on US products to enter Canada tariff-free expanding to 57,000 MT from the current level of 47,000 MT. Generally speaking, the impact of the USMCA policy on the US broiler industry is modest, except for US exports to Canada. For example, the price of US wings, dark meat, and value-added products in Canada will fall, which causes US exports of dark meat and wings to Canada rise by $15.76 \%$ and $7.31 \%$, respectively. Exports of dark meat rise more than wings because the elasticity of demand in Canada for dark meat is larger than for wings. Because wing meat is produced in fixed proportion with dark meat (see equations (30) and (31) in online supplementary Appendix A6.2), if the demand for dark meat expands more than the demand for wing meat, both wing and breast meat must be produced regardless of market conditions. With demand for dark meat outpacing supply, the price of dark meat rises by $1.13 \%$, causing domestic consumption to fall by $2.51 \%$ and exports to Mexico and ROW to fall by $0.26 \%$ and $0.26 \%$. However, with supply outpacing demand for wing and breast meat, the prices of wing and breast meat fall only slightly. The increase in the price of dark meat leads to a minor rise in domestic consumption of breast meat and wings and a negligible rise in wing exports to Mexico and ROW. US exports of value-added products to Canada rise by $11.98 \%$, which causes a small diversion of exports from Mexico and ROW and a minor decline in domestic consumption.

Production in dark meat and wings (and chicken breasts due to fixed proportion) all rise by just under $0.10 \%$. Production of whole chickens falls as broiler chickens are diverted to dark meat and wing production, causing the production of whole chickens to fall by $0.11 \%$. Interestingly, the quantity of chicken processed for the value-added processing and value-added production both 
Table 4. Sensitivity analysis results

\begin{tabular}{|c|c|c|c|c|}
\hline \multirow[b]{3}{*}{ Variables } & \multicolumn{4}{|c|}{ Corn and soybean price shock ${ }^{a}$} \\
\hline & \multicolumn{2}{|c|}{ Elasticity of substitution } & \multicolumn{2}{|c|}{ Price elasticity for Canada } \\
\hline & $20 \%$ decrease & $20 \%$ increase & $20 \%$ decrease & $20 \%$ increase \\
\hline \multicolumn{5}{|l|}{ Whole chickens } \\
\hline Domestic consumption & 6.66 & 6.72 & 6.71 & 6.68 \\
\hline \multicolumn{5}{|l|}{ Chicken breast } \\
\hline Domestic consumption & 2.94 & 2.96 & 2.94 & 2.96 \\
\hline \multicolumn{5}{|l|}{ Chicken wings } \\
\hline Domestic consumption & 3.14 & 3.17 & 3.15 & 3.16 \\
\hline Exports to Mexico & 1.13 & 1.14 & 1.13 & 1.13 \\
\hline Exports to Canada & 3.04 & 3.06 & 2.43 & 3.68 \\
\hline Exports to ROW & 1.10 & 1.11 & 1.10 & 1.10 \\
\hline \multicolumn{5}{|l|}{ Dark meat } \\
\hline Domestic consumption & 11.86 & 11.97 & 12.27 & 11.57 \\
\hline Exports to Mexico & 1.20 & 1.21 & 1.24 & 1.17 \\
\hline Exports to Canada & 11.41 & 11.52 & 9.34 & 13.51 \\
\hline Exports to ROW & 1.16 & 1.18 & 1.20 & 1.14 \\
\hline \multicolumn{5}{|l|}{ Value-added } \\
\hline Domestic consumption & 2.49 & 2.51 & 2.50 & 2.49 \\
\hline Exports to Mexico & 0.56 & 0.57 & 0.56 & 0.56 \\
\hline Exports to Canada & 2.44 & 2.46 & 1.69 & 2.94 \\
\hline Exports to ROW & 0.55 & 0.56 & 0.55 & 0.55 \\
\hline
\end{tabular}

aThe results indicate percent changes from the baseline.

fall slightly, despite the export of value-added products to Canada rising slightly. This implies resources are being drawn from both whole chickens and chickens processed for the value-added processing to chicken parts, and exports to Canada do not boost production but divert domestic sales and exports to Mexico and ROW. The changes in production are small because the enhanced access to Canada's market is modest.

The upstream segments (grow-out farms, hatcheries, breeder farms, feed mills, and corn and soybean meal) all benefit because of the expanded demand for live chickens (all percent changes are below $0.5 \%$ for these upstream segments). The price of live chickens and quantity of production expand, which raises demand for all upstream goods, increasing both quantity produced and price of DOC, fertilized eggs, broiler feed, and corn and soybean meal.

\subsection{Sensitivity analysis}

To gain further insight into the behavior and results of the broiler supply chain model, we conduct sensitivity analyses for assumptions of the elasticity of substitution between inputs for feed mill and grow-out farms segments and Canadian, Mexican, and ROW elasticity of demand by considering a $20 \%$ increase and decrease in these parameters. For the sensitivity analysis, we focus on the reduction in the price of corn and soybean meal following the US-China trade war and report the result for domestic consumption and exports in Tables 4 and 5. Because the elasticity of 
Table 5. Sensitivity analysis results

\begin{tabular}{|c|c|c|c|c|}
\hline \multirow[b]{3}{*}{ Variables } & \multicolumn{4}{|c|}{ Corn and soybean price shock ${ }^{a}$} \\
\hline & \multicolumn{2}{|c|}{ Price elasticity for Mexico } & \multicolumn{2}{|c|}{ Price elasticity for ROW } \\
\hline & $20 \%$ decrease & $20 \%$ increase & $20 \%$ decrease & $20 \%$ increase \\
\hline \multicolumn{5}{|l|}{ Whole chickens } \\
\hline Domestic consumption & 6.72 & 6.67 & 6.72 & 6.67 \\
\hline \multicolumn{5}{|l|}{ Chicken breast } \\
\hline Domestic consumption & 2.93 & 2.97 & 2.93 & 2.97 \\
\hline \multicolumn{5}{|l|}{ Chicken wings } \\
\hline Domestic consumption & 3.15 & 3.15 & 3.15 & 3.15 \\
\hline Exports to Mexico & 0.90 & 1.36 & 1.13 & 1.13 \\
\hline Exports to Canada & 3.05 & 3.05 & 3.05 & 3.05 \\
\hline Exports to ROW & 0.88 & 1.33 & 0.88 & 1.32 \\
\hline \multicolumn{5}{|l|}{ Dark meat } \\
\hline Domestic consumption & 12.67 & 11.24 & 12.50 & 11.39 \\
\hline Exports to Mexico & 1.02 & 1.37 & 1.26 & 1.15 \\
\hline Exports to Canada & 12.20 & 10.82 & 12.03 & 10.96 \\
\hline Exports to ROW & 0.99 & 1.33 & 0.98 & 1.35 \\
\hline \multicolumn{5}{|l|}{ Value-added } \\
\hline Domestic consumption & 2.51 & 2.49 & 2.51 & 2.49 \\
\hline Exports to Mexico & 0.45 & 0.67 & 0.56 & 0.56 \\
\hline Exports to Canada & 2.46 & 2.44 & 2.46 & 2.44 \\
\hline Exports to ROW & 0.45 & 0.67 & 0.44 & 0.66 \\
\hline
\end{tabular}

aThe results indicate percent changes from the baseline.

substitution impacts supply and demand functions along the supply chain, changes in these parameters affect the results. Also, since the literature does not provide estimates for Canadian, Mexican, and ROW demand price elasticities, we conduct sensitivity analyses for these parameters, which has direct effects on the quantity of trade flow between the United States and these countries.

A lower elasticity of substitution leads to a slight fall in domestic consumption and exports of all chicken products relative to the main results reported in Table 2, but the drop is modest. Domestic consumption and exports decline slightly as the elasticity of substitution falls because, with the decline in the price of corn and soybean meal, the breeder farms and grow-out farms have less flexibility to enhance feed output by substituting away from other inputs in the feed segment. The smaller impact on feed dampens the results throughout the supply chain. The converse is true for a higher elasticity of substitution.

With lower and higher elasticity of demand for Canadian, Mexican, and ROW, the sensitivity results show modest impacts on most variables. However, with a lower Canadian elasticity of demand, exports to Canada fall slightly. In general, fewer exports to Canada imply that more broiler products are available for exports to Mexico and ROW and domestic consumption. Relative to the main analysis, total production of whole chickens and value-added products 
increases marginally, whereas total production of chicken parts declines slightly (not reported in Table 4). Therefore, domestic consumption of whole chickens and value-added production rises slightly, relative to the main results in Table 3. For chicken parts, domestic consumption of dark meat rises, but domestic consumption of chicken breast meat falls. Even with lower production, consumption of dark meat rises because exports to Canada fall. However, because the United States has no exports to Canada to offset the decline in production, domestic consumption of breast meat falls. For chicken wings, the decline in production is offset by the fall in exports to Canada and domestic consumption is unaffected. The results for the sensitivity analysis for Mexico and ROW are similar to those of Canada.

In summary, the sensitivity analysis reveals that changes in the elasticity of substitution and ROW elasticity of demand do impact the results, but the impacts are modest. Furthermore, the conclusions from the main results in the preceding sections are maintained.

\section{Discussion and conclusions}

This paper builds a comprehensive supply chain model of the US broiler industry that accounts for corn and soybean meal, feed mills, breeders, hatcheries, grow-out farms, broiler processing, value-added processing, and international trade. This broiler supply chain model is calibrated based on parameters from the literature and US broiler data. Recent developments in US international trade policy-the US-China trade war and the USMCA trade agreement-can impact the broiler supply chain. China's retaliatory tariffs on corn and soybeans led to an oversupply of corn and soybeans in the US market leading to a decline in feed costs. Also, if the USMCA trade agreement is signed by the three North American countries, the US broiler industry will have enhanced access to Canada's market. Therefore, this study considers two counterfactual scenarios: the first scenario simulates the effects of a shock to the corn and soybean meal prices due to corn and soybeans tariffs imposed by China on the US broiler supply chain. The second scenario analyzes the impacts of the change in the Canadian TRQ as proposed under the USMCA throughout the entire broiler supply chain.

The results from the first scenario suggest that the lower US price of feed resulting from the Chinese tariffs on corn and soybeans largely benefits the broiler supply chain because cost of production declines which expands production at every level. As a result, prices for every segment (except fertilized eggs and DOC) fall. Specifically, as the price of corn and soybeans in the US market falls, feed supply increases which depresses the feed price and directly lowers the production costs of breeders and grow-out farms. The lower feed costs cause production of breeders and grow-out farmers to rise, which increases demand for DOC and thus fertilized eggs by grow-out farmers. Because feed directly enters both breeder farm and grow-out farms, it is ex ante unclear whether the supply effect through breeders or demand effect through growout farms will dominate and the price of DOC will rise or fall. The results reveal that the increase in demand outweighs the increase in supply, causing the price of fertilized eggs and DOC to rise.

The increase in broiler chickens lowers the price of broiler chickens, which lowers the cost for all downstream segments. As a result, production expands and prices decline. With lower prices, both domestic and international consumers of whole chickens, chicken parts (wings, chicken breast, and dark meat), and value-added chicken products benefit as consumption expands. Thus, while the Chinese tariff on corn and soybeans undoubtedly makes corn and soybean producers worse off, the chicken industry benefits from lower costs.

While US consumption of dark meat rises the most in percentage term, it increases the least in differences because initial consumption of dark meat is low. Furthermore, consumption of breast meat expands the most in differences, followed by value-added products. These results occur because US consumers largely favor white meat and processed chicken products over dark meat. Consequently, US exports of dark meat rise the most both in percentage terms and differences. 
The results from the second scenario indicate that the enhanced access into the Canadian market resulting from a USMCA deal has modest impacts on aggregate production and prices for the US broiler supply chain. This is because the quota only falls by $17.5 \%$ for the TRQ and the tariff rates remain unchanged. The largest impacts of USMCA will occur in US exports of dark meat and value-added products to Canada, which rise at the expense of exports to Mexico and ROW. Because chicken wings are produced in fixed proportion to dark meat and the expansion of exports of wing meat to Canada is relatively low compared to dark meat, the increase in total wing meat production is substantial enough for both exports and domestic consumption to rise. Also, because chicken breast meat production is in fixed proportion to dark meat and breast meat is not exported, domestic consumption of breast meat falls. Finally, to expand production of exported commodities, broilers are diverted from whole chicken sales to the exported commodities, and domestic consumption of whole chickens falls.

The sensitivity analysis provides insight into how the simulation behaves under different assumptions for the elasticity of substitution between inputs in the feed mill and grow-out farm segments and elasticity of demand for Canada, Mexico, and ROW. In general, a lower elasticity of substitution reduces the ability of feed mill and grow-out farm to switch between inputs, which leads to smaller overall impacts. A lower elasticity of demand for a given country results in fewer exports (relative to the case with a higher elasticity of demand) to that country as domestic consumption and exports to other countries rise.

From a policy perspective, the US-China trade war benefits the broiler industry because of lower feed prices. However, we caution against overinterpreting this result because (1) this analysis provides a narrow view of the overall trade war and (2) the broiler industry is a small segment of the overall corn and soybean market. Enhanced market access through USMCA benefits the US broiler industry because both production and prices rise, implying enhanced profitability through the supply chain. However, the overall impact of USMCA is moderate because the expansion of the quota is modest relative to the overall size of the industry.

Supplementary material. To view supplementary material for this article, please visit https://doi.org/10.1017/aae.2020.5

Acknowledgements. We gratefully acknowledge the editorial coordination by the editor Michael Reed and three anonymous reviewers.

\section{References}

Arumugam, N. The Dark Side of the Bird. Technical report, The Slate Group, The Graham Holdings Company, 2011. Internet site: https://slate.com/human-interest/2011/01/americans-overwhelmingly-prefer-white-chicken-meat-what-happens-to-thedark-parts.html (Accessed October 15, 2018).

Awokuse, T.O., and J.C. Bernard. "Spatial Price Dynamics in U.S. Regional Broiler Markets." Journal of Agricultural and Applied Economics 39,3(2007):447-56.

Awokuse, T.O., and Y. Yuan. "The Impact of Exchange Rate Volatility on US Poultry Exports." Agribusiness: An International Journal 22,2(2006):233-45.

Cang, A., and P. Sedgman. China Strikes at Trump's Rural Heartland with Tariff on Soybeans. Bloomberg, 2018. Internet site: https://www.bloomberg.com/news/articles/2018-04-04/china-to-levy-25-tariffs-on-u-s-soybean-imports-cctvreports (Accessed October 15, 2018).

Chicken Parts. Chicken Cuts. Australian Chicken Meat Federation, 2018. Internet site: https://www.chicken.org.au/chickencuts/ (Accessed April 11, 2019).

Clauer, P. Modern Meat Chicken Industry. Penn State Extension, 2012. Internet site: https://extension.psu.edu/modern-meatchicken-industry (Accessed July 24, 2018).

Corn Trade. U.S. Corn Exports to China Significant Impact from New Chinese Ag and Trade Policies. Agricultural Marketing Resource Center, 2017. Internet site: https://www.agmrc.org/renewable-energy/renewable-energy-climate-change-report/ renewable-energy-climate-change-report/july-2017-report/us-corn-exports-to-china-significant-impact-from-new-chineseag-and-trade-policies (Accessed August 30, 2018).

Corong, E., A.C. Selva, G. Batta, R. Keeney, and D. van der Mensbrugghe. “The Standard GTAP Model, Version 7.” Journal of Global Economic Analysis 2,1(2017). Internet site: http://doi.org/10.21642/JGEA.020101AF (Accessed August 30, 2018). 
Dahlgran, R.A., and D.G. Fairchild. "The Demand Impacts of Chicken Contamination Publicity-A Case Study." Agribusiness: An International Journal 18,4(2002): 459-74.

Daniels, J. Rising U.S.-China Trade Tensions “Couldn't Come at a Worse Time”: Iowa Agriculture Secretary. CNBC, 2018. Internet site: https://www.cnbc.com/2018/09/19/escalation-in-trade-war-comes-at-worse-time-says-iowa-ag-official.html (Accessed August 30, 2018).

Davis, C.G., D. Harvey, S. Zahniser, F. Gale, and W.M. Liefert. Assessing the Growth of U.S. Broiler and Poultry Meat Export. Technical Report Livestock, Dairy, and Poultry Outlook, No. LDPM-231-01, Economic Research Service, U.S. Department of Agriculture, 2013. Internet site: https://www.ers.usda.gov/publications/pub-details/?pubid=37532 (Accessed August 21, 2018).

Davis, C.G., A. Muhammad, D. Karemera, and D. Harvey. "The Impact of Exchange Rate Volatility on World Broiler Trade." Agribusiness: An International Journal 30,1(2014):46-55.

FAPRI. Documentation of the FAPRI Modeling System. Technical Report FAPRI-UMC Report 12-04, College of Agriculture, Food, and Natural resources, University of Missouri, 2004. Internet site: https://www.fapri.missouri.edu/wp-content/ uploads/2015/03/FAPRI-MU-Report-12-04.pdf (Accessed August 24, 2018).

FAPRI. FAPRI Models. Technical Report Issue 2, Food and Agricultural Policy Research Institute, 2018. Internet site: http:// www.fapri.iastate.edu/models/ (Accessed July 11, 2018).

Goodwin, H., A.M. McKenzie, and H. Djunaidi. "Which Broiler Part is the Best Part?" Journal of Agricultural and Applied Economics 35,3(2003):483-95.

Goodwin, H.L. "Location of Production and Consolidation in the Processing Industry: The Case of Poultry." Journal of Agricultural and Applied Economics 37,2(2005): 339-46.

Hernandez, G., and A. Hernandez. Mexico Poultry and Products Annual. Technical Report MX5036, U.S. Department of Agriculture, Foreign Agricultural Service, 2015. Internet site: https://gain.fas.usda.gov/Recent\%20GAIN\%20Publications/ Poultry\%20and\%20Products\%20Annual_Mexico\%20City_Mexico_9-3-2015.pdf (Accessed April 10, 2019).

Holt, M.T., and A.M. McKenzie. "Quasi-rational and Ex-Ante Price Expectations in Commodity Supply Models: An Empirical Analysis of the U.S. Broiler Market.” Journal of Applied Econometrics 18,4(2003): 407-26.

IFEEDER. 2016 U.S. Animal Food Consumption Report. Instutute for Feed Education \& Research, Decision Innovation Solutions, 2017. Internet site: https://www.afia.org/pub/?id=49AB0CF7-F3ED-766D-F8F0-82EEB09179C8 (Accessed November 2, 2017).

MacDonald, J.M. Technology, organization, and financial performance in U.S. broiler production. Technical Report EIB-126, 2014.

Marchant, M.A., and H.H. Wang. "Theme Overwiew: U.S.--China Trade Dispute and Potential Impacts on Agriculture." Choices 33,2(2018): 1-3.

Moschini, G. and K.D. Meilke. "Tariffication with Supply Management: The Case of the US-Canada Chicken Trade." Canadian Journal of Agricultural Economics/Revue canadienne d'agroeconomie 39,1(1991): 55-68.

Murphy, J.P., G.C. Ames, J.E. Epperson, and N.R. French. "International Poultry Trade and the GATT." Journal of International Food \& Agribusiness Marketing 4,3(1993): 57-76.

NCC. How Broilers are Marketed. National Chicken Council, 2018. Internet site: https://www.nationalchickencouncil.org/ about-the-industry/statistics/how-broilers-are-marketed/ (Accessed July 25, 2018).

OECD. Aglink-Cosimo Model Documentation: A Partial Equilibrium Model of Eorld Agricultural Markets. Technical report, Organisation for Economic Co-operation, 2014. Internet site: http://www.agri-outlook.org/about/Aglink-Cosimo-modeldocumentation-2015.pdf (Accessed August 25, 2018).

Ollinger, M. "Structural change in the meat and poultry industry and food safety regulations." Agribusiness 27,2(2011): 244-57.

Ollinger, M., J.M. MacDonald, and M. Madison. "Technological change and economies of scale in U.S. poultry processing." American Journal of Agricultural Economics 87,1(2005): 116-29.

Perry, J., D. Banker, and R. Green. Broiler Farms' Organization, Management, and Performance. U.S. Department of Agriculture, Economic Research Service, 1999. Internet site: https://www.ers.usda.gov/publications/pub-details/?pubid=42211 (Accessed July 24, 2018).

Peterson, E.B., and D. Orden. "Effects of Tariffs and Sanitary Barriers on High-and Low-Value Poultry Trade." Journal of Agricultural and Resource Economics 30,1(2005):109-27.

Reimund, D.A., J.R. Martin, and C.V. Moore. Structural Change in Agriculture: The Experience for Broilers, Fed Cattle, and Processing Vegetables. Technical Report TB-1648, 1981.

Rutherford, T. Lecture Notes on Constant Elasticity Functions. Technical report, University of Colorado, 2002. Internet site: http://www.gamsworld.org/mpsge/debreu/ces.pdf (Accessed July 14, 2018).

Salin, D., W. Hahn, and A. Somwaru. "Economic Evaluation of Non-Tariff Trade Barriers: Sanitary Regulations and the Broiler Market in the Western Hemisphere." Journal of Economic Integration 20,1(2005):158-84.

Schweihofer, J.P. Carcass Dressing Percentage and Cooler Shrink. Michigan State University, 2011. Internet site: https://www. canr.msu.edu/news/carcass_dressing_percentage_and_cooler_shrink (Accessed April 11, 2019).

Suh, D.H., and C.B. Moss. "Dynamic Interfeed Substitution: Implications for Incorporating Ethanol Byproducts into Feedlot Rations." Applied Economics 48,20(2016):1893-901.

Swanson, K., J. Coppess, and G. Schnitkey. Trade Timeline and Corn and Soybean Prices. Farmdoc Daily 8 (141). Department of Agricultural and Consumer Economics, University of Illinois at Urbana-Champaign, 2018. 
Thomsen, M.R., and A.M. McKenzie. "Market Incentives for Safe Foods: An Examination of Shareholder Losses from Meat and Poultry Recalls." American Journal of Agricultural Economics 83,3(2001):526-38.

Transportation Cost. Freight Rates. Personal Correspondence with Nicole Twiford-McKewon, Manager Bulk Commodity Pricing, Bulk Commodity Rates and Commerce, Tyson Fresh Meats, April 15, 2019.

Truckers Report. Facts about trucks - everything you want to know about eighteen wheelers. Truckers Report. Internet site: https://www.thetruckersreport.com/facts-about-trucks/ (Accessed April 11, 2019).

UNComtrade. Un comtrade database. United Nations Statistics Division, 2018. Internet site: https://comtrade.un.org/data/ (Accessed August 27, 2018).

U.S. Bureau of Labor Statistics. Databases, Tables and Calculators by Subject. U.S. Bureau of Labor Statistics, 2018. Internet site: https://www.bls.gov/data/ (Accessed July 25, 2018).

USDA. Assessing the Growth of U.S. Broiler and Poultry Meat Exports. U.S. Department of Agriculture, Economic Research Service, 2018a. Internet site: http://www.clientadvisoryservices.com/Downloads/ldpm-231-01-with-keywords.pdf (Accessed July 24, 2018).

USDA. Chapter Four. Parity Prices, Parity Ratio, and Feed Price Ratios. U.S. Department of Agriculture, National Agricultural Statistics Service, 2018b. Internet site: https://www.nass.usda.gov/Surveys/Guide_to_NASS_Surveys/Prices/Chapter\% 20Four\%20Parity\%20and\%20Feed\%20Price\%20Ratios\%20v10.pdf (Accessed July 24, 2018).

USDA. Feed Grains Custom Query. U.S. Department of Agriculture, Economic Research Service, 2018c. Internet site: https:// data.ers.usda.gov/FEED-GRAINS-custom-query.aspx (Accessed July 23, 2018).

USDA. Global Agricultural Trade System Online. U.S. Department of Agriculture, Foreign Agricultural Service, $2018 \mathrm{~d}$. Internet site: https://apps.fas.usda.gov/gats/default.aspx/ (Accessed August 3, 2018).

USDA. Livestock and Meat Domestic Data. U.S. Department of Agriculture, Economic Research Service, 2018e. Internet site: https://www.ers.usda.gov/data-products/livestock-meat-domestic-data/livestock-meat-domestic-data (Accessed July 24, 2018).

USDA. Livestock and Poultry: World Markets and Trade. U.S. Department of Agriculture, Foreign Agricultural Service, $2018 \mathrm{f}$. Internet site: https://www.fas.usda.gov/data/livestock-and-poultry-world-markets-and-trade (Accessed December, 2018).

USDA. Poultry Market News. U.S. Department of Agriculture, Agricultural Marketing Service, 2018g. Internet site: https:// www.ams.usda.gov/market-news/chicken-market-news-reports (Accessed August 30, 2018).

USDA. Quick Stats. U.S. Department of Agriculture, National Agricultural Statistics Service, (2018h). Internet site: https:// quickstats.nass.usda.gov (Accessed July 23, 2018).

USSEC. Conversion Table. U.S. Soybean Export Council, 2018. Internet site: https://ussec.org/resources/conversion-table/

USTR. United States-Mexico-Canada Agreement, 2018. Internet site: https://ustr.gov/trade-agreements/free-trade-agreements/ united-states-mexico-canada-agreement, Free Trade Agreements, Office of the United States Trade Representative.

Vukina, T., and P. Leegomonchai. "Political Economy of Regulation of Broiler Contracts." American Journal of Agricultural Economics 88,5(2006): 1258-65.

Ward, C.E. Vertical integration comparison: Beef, pork, and poultry. Technical Report, Department of Agricultural Economics, Oklahoma State University. Paper Presented at the Western Agricultural Economics Association, 1997.

Weaver, M. Poultry: Industry and Trade Summary. Technical Report Publication ITS-10, U.S. International Trade Commission, Washington, DC, 2014.

Wieck, C., S.W. Schlüter, and W. Britz. "Assessment of the Impact of Avian Inuenza-Related Regulatory Policies on Poultry Meat Trade and Welfare.” The World Economy 35,8(2012):1037-52.

World Trade Organization. Tariff Analysis Online, 2018. Internet site: http://tariffdata.wto.org/ (Accessed April 14, 2018).

World Trade Organization. Notifications, 2019. Internet site: https://docs.wto.org/dol2fe/Pages/FE_Browse/FE_B_S006.aspx (Accessed May 6, 2019).

Zhou, L., L. Li, and L. Lei. "Avian Inuenza, Non-Tariff Measures and the Poultry Exports of China." Australian Journal of Agricultural and Resource Economics 63,1(2019): 72-94.

Cite this article: Unveren H and Luckstead J (2020). Comprehensive Broiler Supply Chain Model with Vertical and Horizontal Linkages: Impact of US-China Trade War and USMCA. Journal of Agricultural and Applied Economics 52, 368-384. https:// doi.org/10.1017/aae.2020.5 